\title{
ANALYTIC NETWORK PROCESS (ANP): AN APPROACH TO ESTIMATE THE COLOMBIAN BABY DIAPERS MARKET SHARE
}

\author{
Erika Neira \\ Industrial Engineer \\ Universidad de los Andes \\ Bogotá, Colombia \\ E-mail: eri-neir@uniandes.edu.co \\ Mario Castillo* \\ Industrial Engineering Deparment \\ Universidad de los Andes \\ Bogotá, Colombia \\ E-mail: mcastill@uniandes.edu.co \\ Diana Lesmes \\ Industrial Engineering Department \\ Universidad de los Andes \\ Bogotá, Colombia \\ E-mail: $\underline{\text { d-lesmes@uniandes.edu.co }}$
}

\begin{abstract}
Colombian baby diapers market is aggressive, competitive and dynamic. For this reason, Kimberly-Clark Corporation in Colombia is interested on knowing how the relevant components of the diapers market affect their brands' market share. Considering that the conditions of the problem are adjusted perfectly to the ANP structure, we developed a model based on this tool to estimate the market share for the Corporation diapers' brands. The relevant components on the model are: principal brands, consumer preferences, distribution channels, segments, and Colombian regions. The results were validated by comparing the ANP model's estimations with market share's ones done by Nielsen. These results show that there is no significant difference between the ANP results and the Nielsen statistics. Results also indicate that the model is a good approach to represent this market's behavior, and, therefore, Kimberly Clark Corporation in Colombia is willing to implement the model.
\end{abstract}

Keywords: Analytic Network Process, market share, diapers

\section{Introduction}

Colombian Baby Diapers Market is an aggressive, competitive and dynamic market because of its historical stable size, low growth rate and a variety of competitors that offer high quality products at lower prices. Based on this, Colombiana Kimberly Colpapel S.A. (CKC), the Kimberly-Clark Corporation in Colombia, is interested on knowing how relevant components of diapers market affect the three principal brands' market share, with which a competitive analysis of Colombian Market comes into sight. For this issue, a project based on a Decision Theory approach was developed. It considers relevant components' identification, and their influences and importance in the market, as the inputs to estimate the brand's market share.

Based on a diapers market's literature revision, the Colombian Diapers Market could be described as directed by three important brands: Winny, Pequeñín and Huggies. They compete by increasing their

\footnotetext{
* Corresponding author
} 
product's quality (Millward Brown Región Andina, 2008). That is, offering products to the consumers with better quality at the same price. Although their prices are stable, each brand has a sub-brand for each socioeconomic level with a different pricing strategy. To distinguish from the others, each company launches benefit plans as additional services for brand loyalty. Commerce competition in the distribution channel plays as well an important role in this market. Each actor in the channel plays a double roll: as a direct client of the brands and as a direct seller for the consumer. Actually, the most important channels are hypermarkets, supermarkets, drugstores, retail stores, and specialized babies' stores. In Colombia, each region has its own buyer behavior, as commerce behavior does, according to Nielsen. The movements of the market that influence market share could be modeled by a Decision Making Tool: the Analytic Network Process because this method allows us to view the market as a system of interactions among the market's relevant components previously identified (Saaty, 2001).

The first step to model this situation is to obtain the necessary information. In this process are included employees' judges, marketing research studies, and quantitative information. With this information, we identified the market's relevant components: 1) principal brands; 2) consumer preferences; 3) actors in the distribution channel; 4) Socioeconomic Product Segments; and 5) Colombian regions.

\section{ANP model for Colombian diapers market}

Based on the preceding information, the network that represents this situation was designed. The components are $\mathrm{C}=\left\{\mathrm{C}_{1}, \mathrm{C}_{2}, \mathrm{C}_{3}, \mathrm{C}_{4}, \mathrm{C}_{5}\right\}$. Each component is defined by its own elements. These definitions are presented on Table 1 below:

Table 1. Diapers' component definitions

\begin{tabular}{|c|c|}
\hline Components & Elements \\
\hline $\begin{array}{l}\mathrm{C}_{1}: \text { Alternatives }- \\
\text { principal diapers' brands }\end{array}$ & $\begin{array}{l}\text { - } \mathrm{E}_{11}: \text { Winny } \\
\text { - } \mathrm{E}_{12}: \text { Pequeñín } \\
\text { - } \mathrm{E}_{13}: \text { Huggies } \\
\text { - } \mathrm{E}_{14}: \text { Other Brands }\end{array}$ \\
\hline $\mathrm{C}_{2}$ : Brands' consumer preferences & $\begin{array}{ll}\text { - } & \mathrm{E}_{21}: \text { Price } \\
\text { - } & \mathrm{E}_{22}: \text { Quality } \\
\text { - } & \mathrm{E}_{23}: \text { Advertising } \\
\text { - } & \mathrm{E}_{24}: \text { Brand Loyalty }\end{array}$ \\
\hline $\mathrm{C}_{3}:$ Actors in the distribution channel & $\begin{array}{ll} & \mathrm{E}_{31}: \text { Hypermarkets } \\
\text { - } & \mathrm{E}_{32}: \text { Retail Stores } \\
\text { - } & \mathrm{E}_{33}: \text { Drugstores } \\
\text { - } & \mathrm{E}_{34}: \text { Specialized Babies' Stores } \\
\text { - } & \mathrm{E}_{35}: \text { Supermarkets }\end{array}$ \\
\hline $\mathrm{C}_{4}$ : Socioeconomic segments & $\begin{array}{ll}- & \mathrm{E}_{41}: \text { Premium } \\
\text { - } & \mathrm{E}_{42}: \text { Value } \\
\text { - } & \mathrm{E}_{43}: \text { Economy } \\
\end{array}$ \\
\hline $\mathrm{C}_{5}$ : Colombian regions & $\begin{array}{ll}\text { - } & \mathrm{E}_{51}: \text { Atlántico } \\
\text { - } & \mathrm{E}_{52}: \text { Antioquia } \\
\text { - } & \mathrm{E}_{53}: \text { Centro } \\
\text { - } & \mathrm{E}_{54}: \text { Pacífico } \\
\text { - } & \mathrm{E}_{55}: \text { Oriente } \\
\text { - } & \mathrm{E}_{56}: \text { Cundinamarca }\end{array}$ \\
\hline
\end{tabular}


As you can see on Table 1, the evaluated alternatives are Winny, Pequeñín, Huggies and other brands. Consumer preferences are determined by price, quality, advertising and brand loyalty. On the other hand, the structure of the distribution channel is based on hypermarkets, retail stores, drugstores, specialized babies' stores and supermarkets. Diapers are classified in three segments: 1) Premium, in which mothers seek well-nice and luxury products for her baby; 2) Value, in which mothers' buyer behavior is based on the degree of the baby's satisfaction; 3) and Economy, in which mothers seek good products at lower prices. Finally, the table defines Colombian regions as Nielsen does, dividing Colombia in 6 regions: Atlántico, Antioquia, Centro, Pacífico, Oriente and Cundinamarca.

The resulting market's network showed below represents the influences among the diapers market's components, modeled in Super Decisions software. These are the influences between the components: $\left\{\left(\mathrm{C}_{1}, \mathrm{C}_{1}\right),\left(\mathrm{C}_{1}, \mathrm{C}_{3}\right),\left(\mathrm{C}_{1}, \mathrm{C}_{4}\right),\left(\mathrm{C}_{2}, \mathrm{C}_{1}\right),\left(\mathrm{C}_{2}, \mathrm{C}_{2}\right),\left(\mathrm{C}_{3}, \mathrm{C}_{1}\right),\left(\mathrm{C}_{3}, \mathrm{C}_{3}\right),\left(\mathrm{C}_{4}, \mathrm{C}_{1}\right),\left(\mathrm{C}_{4}, \mathrm{C}_{4}\right),\left(\mathrm{C}_{5}, \mathrm{C}_{1}\right),\left(\mathrm{C}_{5}, \mathrm{C}_{5}\right)\right\}$. These relationships demonstrate that all the components directly affect the alternatives.

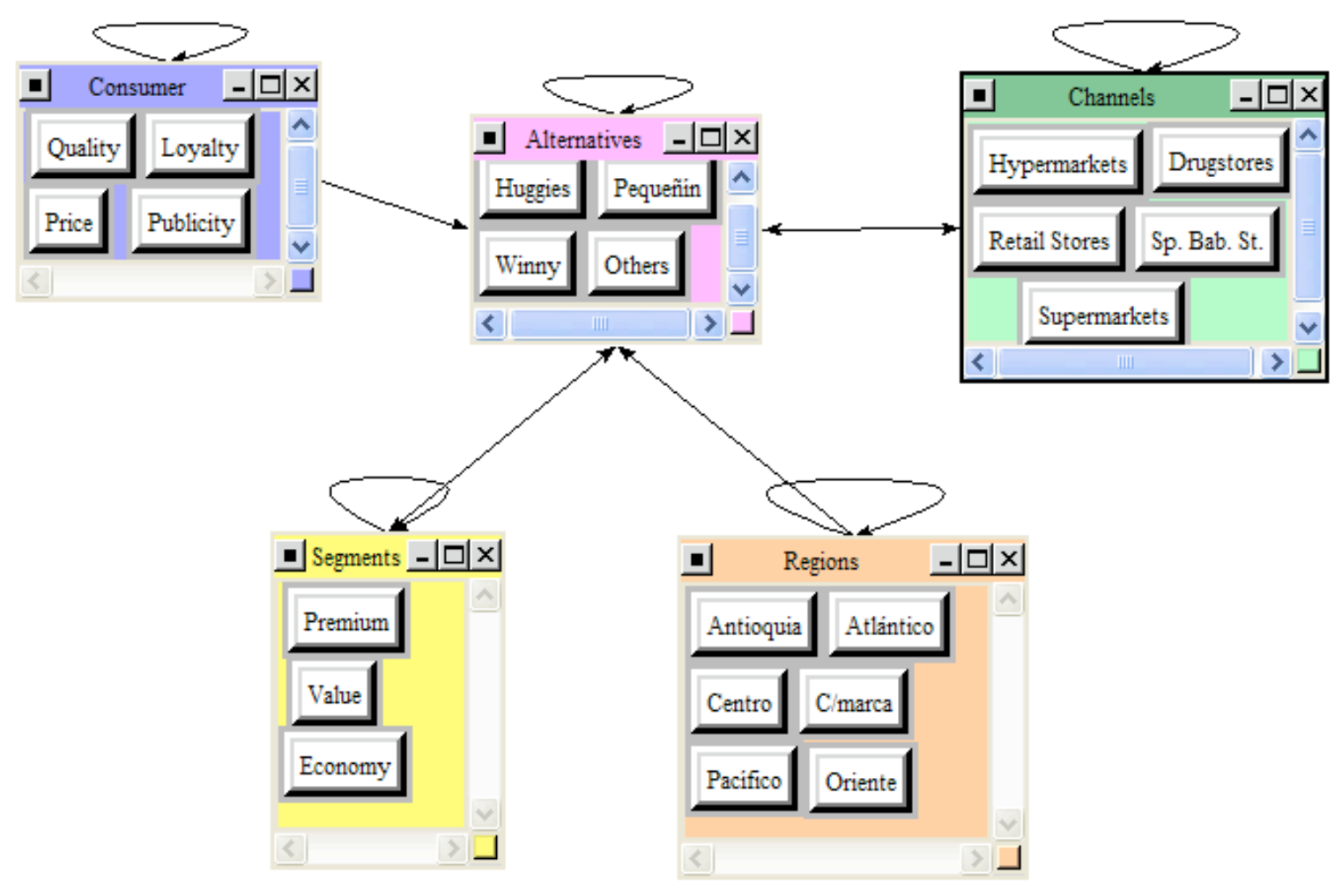

Figure 1. Diapers market's network

Once we have the network, we proceed to construct the component matrix based on the priorities obtained from the pairwise comparison matrices (Saaty, 2001), as the matrix illustrates below. 
Table 2. Components' pairwise comparison matrix with respect to the alternatives

\begin{tabular}{|l|l|l|l|l|}
\hline & Alternatives & Channels & Segments & Priorities \\
\hline Alternatives & 1 & 3 & 4 & 0.625 \\
\hline Channels & $1 / 3$ & 1 & 2 & 0.238 \\
\hline Segments & $1 / 4$ & $1 / 2$ & 1 & 0.137 \\
\hline
\end{tabular}

Inconsistency Ratio $=0.0176$

This matrix represents the influences of the components on the alternatives. Table 2 shows that the alternatives influence on the channels and segments. The priorities of each component, with respect to the alternatives, are on the right column of the matrix. This type of matrix has to be filled for each component of the network.

With the priorities previously obtained, the component matrix could be constructed. Each cell of this matrix is filled with its respective priority, which represents the relative importance of the component in the row with respect to the component in the column (Saaty, 2006), bearing in mind the market share estimation. The resulting component matrix is presented as follows:

Table 3. Component matrix

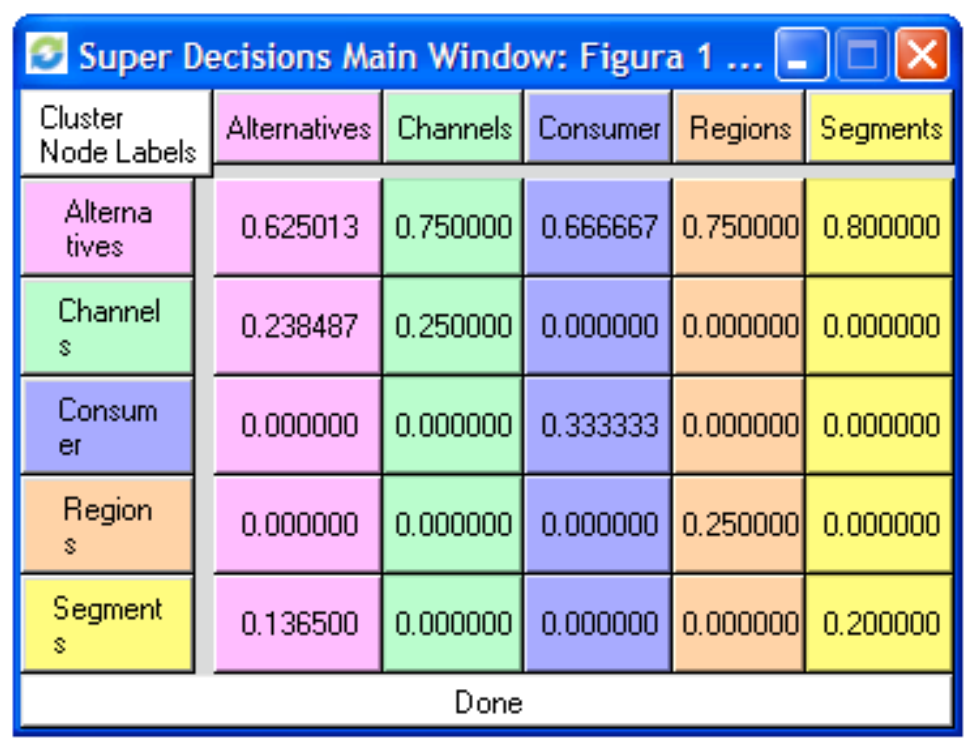

For all the components, the most important one is the alternatives. With respect to the brands, the channels have an importance of $23.8 \%$, and the segments' component one of $13.6 \%$.

Next, we proceed to analyze the element's pairwise comparison matrices. An example of this type of matrix is shown below on Table 4. This matrix represents pairwise comparison of the actors in the distribution channel's components with respect to Huggies. 
Table 4. Pairwise comparison matrix of the distribution channel elements with respect to Huggies

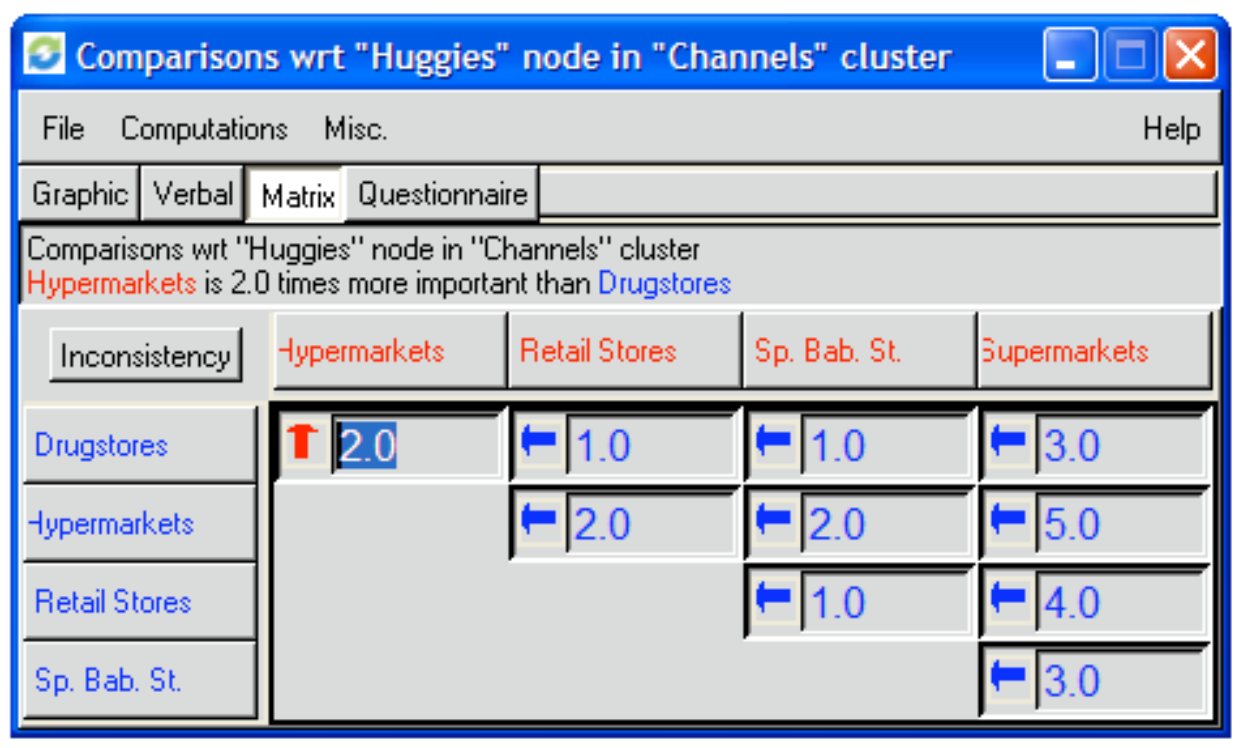

Table 4 gives information concerning to the importance that drugstores, supermarkets, specialized babies' stores and retail store represent to Huggies. For example, the second cell in the first row, moving from the left to the right, indicates that drugstores and retail store are equally important to Huggies. The same comparisons have to be done for all the distribution channels on the matrix to obtain the matrix's priorities shown below.

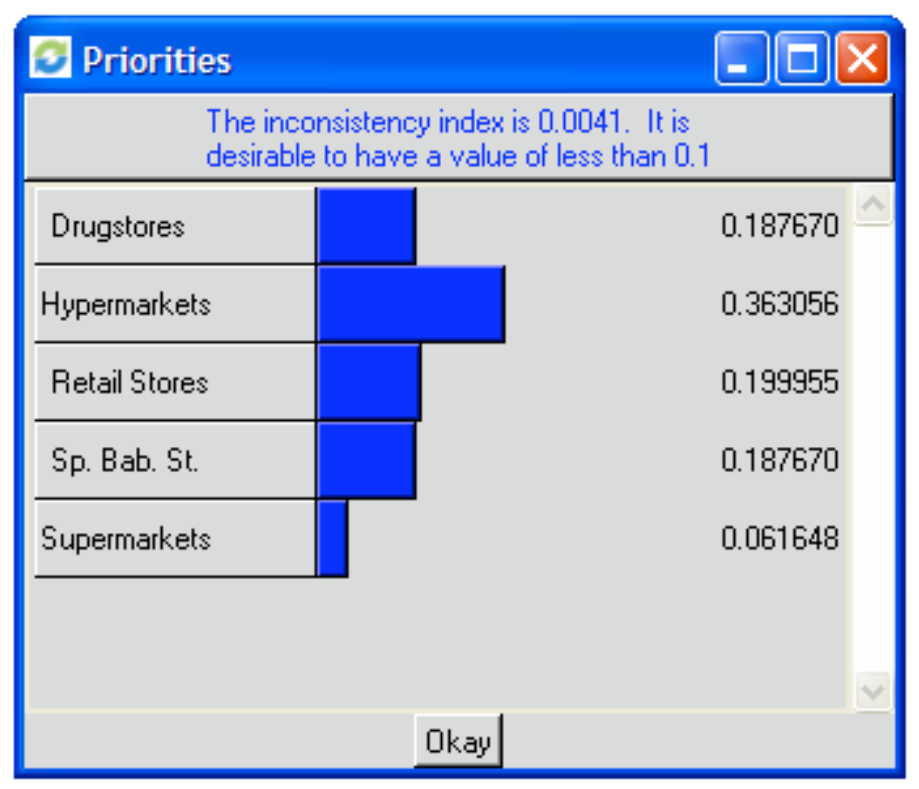

Figure 2. Channel's priorities relative to Huggies

As the reader can see on Figure 2, the most important actors in the distribution channel for Huggies are hypermarkets with $36.3 \%$ of importance, followed by retail stores with $19.9 \%$, drugstores and specialized babies' stores with $18.8 \%$ each one, and ending with supermarkets. 
Once we have completed all the pairwise comparison matrix's priorities, we proceed to construct $21 \times 21$ elements supermatrix. First, the un-weighted supermatrix is constructed after weighting that matrix with the component matrix, and finally, we obtain the limit supermatrix (Saaty, 2006), represented as follows:

Table 5. Weighted Limit Supermatrix

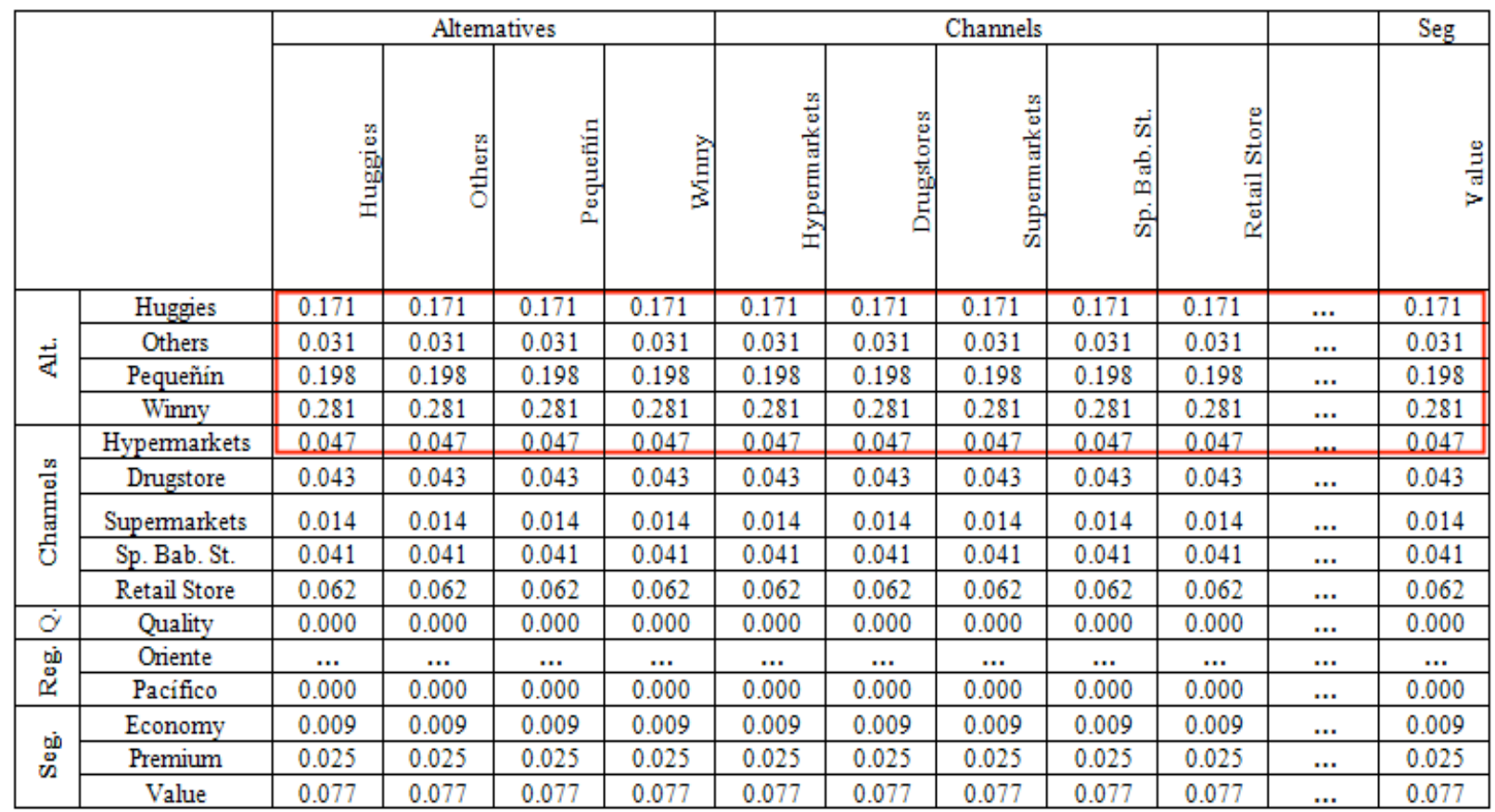

The results are highlighted by the red rectangle on Table 5. Each cell's value is normalized, and represents the estimated value of the market share, as we observe on the next figure.

\begin{tabular}{|c|c|c|c|c|}
\hline Name & Graphic & Ideals & Normals & Raw \\
\hline Huggies & & 0.608615 & 0.251231 & 0.171293 \\
\hline Dthers & & 0.108755 & 0.044893 & 0.030609 \\
\hline Pequeñín & & 0.705164 & 0.291085 & 0.198466 \\
\hline Winny & & 1.000000 & 0.412791 & 0.281447 \\
\hline
\end{tabular}

Figure 3. Diapers market share estimation

Based on the estimations above, the most important brand on Colombian diapers market is Winny with $41.3 \%$ of importance, followed by Pequeñín with $29.1 \%$ and Huggies with $25.1 \%$, and ending with other brands with the rest of importance.

\section{Validation of results vs. actual situation}

To understand the significance of these results, we have to compare them with real statistics. The verification of these results is detailed on Table 6. The statistics were obtained from Nielsen Colombian Diapers' Market Database. We found out that there is no significant difference between de ANP results and Nielsen statistics. 
Table 6. ANP Results vs. Nielsen statistics

\begin{tabular}{|l|r|r|r|}
\hline & \multicolumn{1}{|l|}{ ANP } & \multicolumn{1}{l|}{ Nielsen } & Difference \\
\hline Winny & $41.28 \%$ & $40.30 \%$ & $0.98 \%$ \\
\hline Pequeñín & $29.11 \%$ & $29.90 \%$ & $0.79 \%$ \\
\hline Huggies & $25.12 \%$ & $25.60 \%$ & $0.48 \%$ \\
\hline Other Brands & $4.49 \%$ & $5.00 \%$ & $0.51 \%$ \\
\hline
\end{tabular}

At the same time, this model gives information about the distribution channels' participation in the diapers market and participation in the diapers market by segments. The comparison between these results and their differences is shown below.

Table 7. Channel's ANP results vs. Nielsen statistics

\begin{tabular}{|l|r|r|r|}
\hline & \multicolumn{1}{|l|}{ ANP } & \multicolumn{1}{l|}{ Nielsen } & Difference \\
\hline Hypermarkets & $22.61 \%$ & $21.00 \%$ & $1.61 \%$ \\
\hline Drugstores & $20.88 \%$ & $19.00 \%$ & $1.88 \%$ \\
\hline Supermarkets & $6.77 \%$ & $7.00 \%$ & $0.23 \%$ \\
\hline $\begin{array}{l}\text { Specialized } \\
\text { channel }\end{array}$ & $19.87 \%$ & $20.00 \%$ & $0.13 \%$ \\
\hline Retail stores & $29.87 \%$ & $33.00 \%$ & $3.13 \%$ \\
\hline
\end{tabular}

Table 8. Segment's ANP results vs. Nielsen statistics

\begin{tabular}{|l|r|r|r|}
\hline & \multicolumn{1}{|l|}{ ANP } & \multicolumn{1}{l|}{ Nielsen } & \multicolumn{1}{l|}{ Error } \\
\hline Economy & $8.23 \%$ & $6.29 \%$ & $1.94 \%$ \\
\hline Premium & $22.61 \%$ & $14.00 \%$ & $8.61 \%$ \\
\hline Value & $69.16 \%$ & $78.86 \%$ & $9.69 \%$ \\
\hline
\end{tabular}

Based on the ANP results, we conclude that the most important channels in the Colombian diapers market are the retail stores with $29.87 \%$, followed by hypermarkets with $22.61 \%$, drugstores with $20.88 \%$, specialized babies' stores with $19.87 \%$, ending with supermarkets. These estimations are similar, if compared to Nielsen Statistics.

Additionally, based on ANP, we conclude that the most important segment in this market is Value with $69.16 \%$ of share, followed by Premium with $22.61 \%$, and ending with Economy with $8.23 \%$. The same ranking and similar values are presented in Nielsen statistics, although the comparisons have more differences than the other results mentioned before.

In general, the model's results are good estimations for measuring the brands' participation in the Colombian diapers market, with respect to the Nielsen statistics. Therefore, this ANP model is a good representation of the diapers market's reality.

\section{Conclusions}

The final results of this project are the identification of the Colombian diapers markets' relevant components and its importance and relationships, with which we obtained a tool to make a brand's competitive analysis, made by Kimberly Clark Corporation in Colombia. The model was created through ANP, which brought on a feasible model for representing this market. 
The ANP approach allows us to use quantitative and qualitative information making this methodology flexible. Additionally, the methodology allows us to obtain the estimations faster than the traditional estimation's models, as linear regression or logistic models (Lilien, Gary L., 1946). This, because we count on the experts' perception for making estimations, and therefore, the latest data of diapers' consumption is not needed.

As a final point, it is important to remark that this project is the first example of application the ANP method to estimate market's participation in Colombia. The researching process of papers, monographs, thesis made in Colombia concerning to ANP was made in the most prestigious Colombian universities' websites.

\section{REFERENCES}

Lilien, Gary L. (1946). Marketing engineering: computer-assisted marketing analysis and planning, State College, PA: Institute for the Study of Business Markets, 2004.

Millward Brown Región Andina (2008, Novermber 9). Informe BEM BCC, LAO Colombia presentado para: Kimberly Clark.

Saaty, T. L. (2001). Decision Making with Dependence and Feedback: The Analytic Network Process (Second ed.). Pittsburgh, USA: RWS Publications, 4922 Ellsworth Avenue, Pittsburgh, PA 15213 USA.

Saaty, T. L. (2004, January 13). Lect9-ANP.ppt The Essentials of the Analytic Network Process with Seven Examples. Retrieved February 10, 2008, from Super Decisions Software website: http://www.superdecisions.com/ saaty/Powerpoint\%20Lecture\%20Slides/

Saaty, T. L. (2008). Relative Mesuarement and Its Generalization in Decision Making Why Pairwise Comparisons are Central in Mathematics for the Measurement of Intangible Factors The Analytic Hierarchy/Network Process. RACSAM , 102 (2), 251-318.

Saaty, T. L. (2005). Theory and Applications of the Analytic Network Process. Pittsburgh, USA: RWS Publications.

Saaty, T. L., \& Ozdemir, M. S. (2003). Why the magic number seven plus or minus two. Mathematical and Computer Modelling , 383, 233-244.

Saaty, T. L., \& Vargas, L. G. (2006). Decision Making with the Analytic Network Process Economic, Political, Social and Technological Applications with Benefits, Opportunities, Cost and Risk. United States of America: Springer.

Mintel Internacional Group Ltd. (2007, October). Disposable Baby Products. Chicago, Estados Unidos. 